\title{
Effect of Saline Irrigation Water on Growth and Productivity of Five New Melon Lines
}

\author{
Mohamed E. Abou Kamer ${ }^{1}$ and Mostafa A. Shama ${ }^{2}$
}

\begin{abstract}
Field experiments were conducted during summer seasons of 2018 and 2019 at Soil Salinity Dept., Soil, Water, and Environment Research Institute, Agriculture Research Center, Alexandria Governorate, Egypt, , to investigate the response of five different genotypes of growing melon to three levels of saline irrigation water $(500,2000,4000 \mathrm{mg} / \mathrm{L})$. The included genotypes were Line Mass Matrouh, local genotype $\left(G_{1}\right)$, Line $22\left(G_{2}\right)$, Line 26 $\left(G_{3}\right)$, Line Ideal $\left(G_{4}\right)$ and Line New Matrouh $\left(G_{5}\right)$. Results indicated that traits of plant length and number of branches/plant were negatively significant affected by salinity treatment $(2000,4000 \mathrm{mg} / \mathrm{L})$ during the two studied growing seasons. While date of flowering and number of fruits/plant were not affected by treatments of saline irrigation water across the two seasons. Line $\mathbf{G}_{3}$ recorded the highest mean value for average fruit weight/plant followed by Line $\mathbf{G}_{4}$. Fruit shape index, total soluble solids and fruit moisture content were also significantly positive affected by different levels of water saline. These results clearly indicated that the evaluated melon genotypes differed in their genetic traits. Among genotypes, $G_{3}$ and $G_{4}$ lines showed the highest tolerance to the saline water treatments $(2000,4000 \mathrm{mg} / \mathrm{L})$, so we recommend to use these lines either in areas irrigated with saline water or to be integrated in breeding program to produce more salt tolerant hybrid of melon plant that can be used in cultivating areas irrigated with saline water.

Keywords: Cucumis melo, Irrigation water salinity, yield, fruit quality.
\end{abstract}

\section{INTRODUCTION}

Melon (Cucumis melo L.) is an important horticultural crop which is often cultivated in arid and semi-arid regions, where soil salinity has already been a problem. Melons are major economic fruits that are often cultivated under irrigation in Egypt. Fruits are used in the summer period and are popular because the pulp of the fruit is very refreshing, high nutritional and sweet with a pleasant aroma (Badr and Abou Hussein, 2008). In general, melon plant moderately resistant to salinity and drought conditions (Firdes et al., 2019). According to Maas and Hoffman's (1977) classification, most reports define melons as a moderately sensitive crop (salinity threshold of $1 \mathrm{dS} \mathrm{m^{-1 }}$ and $8.4 \%$ yield decline per $\mathrm{dS} \mathrm{m}^{-1}$ ) ((Shannon and Francois, 1978; Mangal et al., 1988; Maas and Grattan, 1999). Many research studies have been performed growing melons with saline water. These reports showed that yields decline were due to a significant reduction in fruit size, but salt stress caused an increase in parameters of fruit quality, such as total soluble sugars (Medlinger, 1994). Several reports indicated that salt stress brought about an increase in parameters of fruit quality, such as total soluble sugars (TSS) (fcMeiri et al., 1995; Mendlinger, 1994), and fruit appearance (Mendlinger and Fossen, 1993).

Salinity is one of the most important environmental problems that affect the growth and productivity of various crops (Bhaskar and Bingru, 2014). Several studies indicated that crops sensitivity tolerance to water salinity effects may vary among species and cultivars, depending on the regional climatic conditions, soil types, irrigation methods and plant development stage (Dias et al., 2011; Nangare et al., 2013; Medeiros et al., 2014). The negative impact of salinity increases dramatically in arid and semi-arid regions of the world where the majority of developing countries are located (Khan et al., 1999). Salinity not only causes differences between average and potential yields, but also causes a decrease in yield from year to year, which directly affect plant growth through its interaction with metabolic rates and pathways in plants (Rahimi et al., 2012). There is a need better manage salinity problem. Most of new the agricultural reclamation and investment in Egypt depend on irrigation from groundwater, which are often suitable for irrigation in terms of salt, sodium, chloride, calcium and magnesium bicarbonate, chlorides and sulfates. Salinity stress (abiotic pressure) poses a serious problem in reducing yields in many vegetable production areas (Eslamboly and Abdel Wahab, 2014), as well as crop production worldwide, especially in arid and semi-arid regions (Arzani and Ashraf, 2016).

Salinity can affect plant growth in two ways: Osmotic and toxicity effects, the symptoms of chloride toxicity in excessive accumulation may cause burning of the leaf tips or margins, bronzing and premature yellowing, sodium toxicity symptoms are leaf burn, scorch and dead tissue along the outside edges of leaves. High concentrations of sodium in irrigation water can

\footnotetext{
DOI: 10.21608/asejaiqjsae.2021.193571

${ }^{1}$ Cross Pollination Vegetable Dept., Horticulture Research Institute; A.R.C., Egypt.

${ }^{2}$ Soil Salinity Dept., Soil, Water, and Environment Research Institute; A.R.C., Egypt.

Received August 10, 2021, Accepted, September 08, 2021
} 
induce calcium and potassium deficiency in soils low in these nutrients, high levels of sodium in relation to calcium and magnesium, waterlogging may cause the degradation of well-structured soils, leaves usually suffer from toxicity when the dried leaves contain more than $0.2 \%$ sodium or $0.5 \%$ chloride, (https://www.agric.wa.gov.au). Salt stresses can cause several types of damage such as growth inhibition (Dasgan and Koc, 2009). Colla et al., (2006) found that increased salinity in the nutrient solution resulted in a linear decrease in marketable cantaloupe yield compared to control, water salinity significantly decreased cantaloupe total yield but the reduction was minimal under $1.4 \mathrm{ET}_{\mathbf{c}}$ irrigation regime, (Badr and Abou Hussein, 2008). They noted that, although salinity reduce average fruit weight, number of fruits /plant remained the same and water salinity markedly improved fruit quality as total soluble solids and sugar contents increased.

Under certain climatic conditions, information on salts and irrigation management, along with interpretation and analysis of the limits of tolerance to salinity of plant species, are essential in the appropriate choice of crop and cultivar to be exploited in agricultural areas when saline water is available for irrigation, in order to avoid salinization of the areas and guarantee good commercial production (Francisco et al., 2017) . Although melon (Cucumis melo L.) has been stated to have medium tolerance to salinity by different researchers (Shannon and Francois, 1978; Nukaya, et al., 1980; and Meiri and Plaut, 1981), it has also been reported that saline tolerance differs in melons by genotypes, with variables ranging from "sensitive" to "medium tolerant" with respect to yield characteristic (Shannon, et al.,1984; Mangal, et al. 1988; and Mendlinger, and Pasternak 1992.).

The objective of this study was to investigate the growth performance, quality and productivity of five different melon genotypes under different levels of salinity irrigation water.

\section{MATERIAL AND METHODS}

Field experiment was conducted at Soil Salinity Department. Soil, Water, and Environment Research Institute, Agriculture Research Center, Alexandria, Egypt, during summer seasons of 2018 and 2019. Five inbred lines (genetic material) named; Line Mass Matrouh (local genotype) $\left(\mathrm{G}_{1}\right)$, Line $22\left(\mathrm{G}_{2}\right)$, Line 26 $\left(\mathrm{G}_{3}\right)$, Line Ideal $\left(\mathrm{G}_{4}\right)$ and Line New Matrouh $\left(\mathrm{G}_{5}\right)$ were involved in this study. The lines were supplied from the Breeding Program of "Improvement the Cucurbitaceae Vegetables" Project, Horticulture Research Institute.

Three salt concentrations of irrigation water were used with total soluble salts of 500 (tap water as a control), 2000 and $4000 \mathrm{mg} / \mathrm{L}$. The saline water was prepared by mixing tap water electrical conductivity (EC) $0.78 \mathrm{dS} / \mathrm{m}$ with sea water to obtain 3.12 and 6.25 $\mathrm{dS} / \mathrm{m}$ at certain ratios which equals to 500,2000 and $4000 \mathrm{mg} / \mathrm{L}$, respectively.

The experiment was designed as a split-plot with 3 replicates. Treatments were formed by the combination of two factors. Three salt levels of irrigation water (500, 2000 and $4000 \mathrm{mg} / \mathrm{L}$ ) were assigned in the main plots and, five melon inbred lines $\left(G_{1}, G_{2}, G_{3}, G_{4}\right.$ and $\left.G_{5}\right)$ were, randomly, distributed in the subplots. Irrigation treatments started during early vegetative growth 30 days after transplanting keeping the soil moisture content near the field capacity (28\%).

The experimental soil was tested for its physical and chemical properties and presented in Table (1), according to U.S. Salinity Laboratory Staff (1954), For saturation pest extract of the soil, EC was measured by using electrical conductivity meter and $\mathrm{pH}$ by electrical pH-meter (TWT, Germany). Soluble calcium and magnesium were determined by titration with EDTA solution. Potassium and sodium were measured using a flame photometer (Gallenkamp flame analyser, UK). Bicarbonate was determined using $0.01 \mathrm{~N} \mathrm{HCl}$ titration and chloride using titration of silver nitrate solution and potassium chromate as indicator. Sulfate was calculated by difference between soluble cations and anions (Page et al., 1982). Soil organic matter (OM) content was determined by wet oxidation method with $\mathrm{K}_{2} \mathrm{Cr}_{2} \mathrm{O}_{7}$. Soil cation exchange capacity (CEC) and calcium carbonate equivalent were determined according to Page et al., 1982. The particles size distribution of the soil was determined using the hydrometer method (Gee and Bauder, 1986). 
Table 1. The main physical and chemical properties of the experimental soil at the beginning of the two growing seasons (2018 and 2019)

\begin{tabular}{|c|c|c|c|c|c|c|c|c|c|c|c|}
\hline \multirow[b]{2}{*}{ Years } & \multicolumn{11}{|c|}{ Physical properties } \\
\hline & $\begin{array}{l}\text { Sand } \\
\%\end{array}$ & $\begin{array}{l}\text { Silt } \\
\%\end{array}$ & $\begin{array}{c}\text { Clay } \\
\%\end{array}$ & \multicolumn{2}{|c|}{ Soil texture } & pH & $\begin{array}{c}\mathrm{EC} \\
\mathrm{dS} / \mathrm{m}\end{array}$ & $\mathrm{CaC}$ & $\%$ & \multicolumn{2}{|c|}{ OM \% } \\
\hline 2018 & 38.5 & 21.0 & 40.5 & \multicolumn{2}{|c|}{ Clay loam } & 7.87 & 1.69 & & & \multicolumn{2}{|c|}{2.15} \\
\hline 2019 & 38.2 & 21.1 & 40.7 & \multicolumn{2}{|c|}{ Clay loam } & 7.86 & 1.72 & & & \multicolumn{2}{|c|}{2.17} \\
\hline & \multicolumn{5}{|c|}{ Soluble cations (meq/L) } & \multicolumn{3}{|c|}{ Soluble anions (meq/L) } & \multicolumn{3}{|c|}{$\begin{array}{c}\text { Available nutrients } \\
\mathrm{Mg} / \mathrm{kg}\end{array}$} \\
\hline Years & $\mathrm{Ca}^{++}$ & $\mathrm{Mg}^{++}$ & $\mathrm{Na}^{+}$ & $\mathrm{K}^{+}$ & $\mathrm{CO}_{3}^{-}$ & $\mathrm{HCO}_{3}{ }^{-}$ & $\mathrm{CL}^{-}$ & $\mathrm{SO}_{4}^{--}$ & $\mathrm{N}$ & $\mathrm{P}$ & $\mathrm{K}$ \\
\hline 2018 & 5.48 & 4.66 & 9.88 & 0.23 & -- & 8.46 & 3.46 & 8.12 & 80.0 & 17.9 & 38.2 \\
\hline 2019 & 5.51 & 4.68 & 9.65 & 0.25 & -- & 8.41 & 3.47 & 7.94 & 86.4 & 18.2 & 39.1 \\
\hline
\end{tabular}

Seeds were sown in 209 cells tray at $16^{\text {th }}$ April and at $20^{\text {th }}$ March of 2018 and 2019 respectively. Seedlings were transplanted in to field 21 days after sowing, when the second true leaf was fully expanded, then, seedlings were thinned to one plant/hill 3 plants $/ \mathrm{m}^{2}$. Irrigation, fertilization, weeding and pest controls were practiced as recommended by Ministry of Agriculture and land Reclamation (MALR).

Measurements were recorded for vegetative growth characteristics there were plant length $(\mathrm{cm})$, number of branches/plants, flowering date ( days) and fruit maturity date ( days). For yield and yield components; as, total fruit yield/plant $(\mathrm{kg})$, number of fruits/plant and average fruit weight/plant (g). For fruit characteristics; as fruit shape index as reported by Winiger and Ludwing (1974)., placenta hardness (scored from 1 to 10; whereas, 1 denotes soft placenta hardness and 10 refers to extremely hard placenta, fruit netting degree (scored from 1 to 10; whereas, 1 denotes extremely smooth fruit skin, while 10 denotes heavily rough skin fruit, fruit skin color (scored from 1 to 10; whereas, 1 denotes green skin, while 10 denotes yellow skin, fruit total soluble solids (T.S.S.) was determined using the Zeiss hand Refractometer and fruit moisture content was recorded using an oven produced by Fisher Scientific Company, USA.

The obtained data were statistically subjected to ANOVA analysis followed by Duncan's multiple range test (DMRT) at $\mathrm{P}=0.05$ using Costat software program.

\section{RESULTS AND DISCUSSION}

\section{Vegetative Growth Parameter:}

Table (2) showed that, saline water irrigation significantly affected plant length during the two growing seasons. Plant length significantly decreased with increasing water salinity level from 500 to 4000 $\mathrm{mg} / \mathrm{L}$. The highest mean value was recorded with the treatment of $500 \mathrm{mg} / \mathrm{L}$ (control). Other studied traits were not significantly affected by increasing the salinity levels of irrigation water except flowering date during the first season. Similar results was explained by Salem et al., (2017) who clarified that the limitation of plant growth under salinity conditions corresponds to the fact that salinity leads to the accumulation of certain ions and deficiency of other ions and the reduction of external water potential in the cell. Moreover, the decrease in plant growth may be due to interruptions in metabolic activities affected by decreased water absorption and disturbance in water balance (Fahad et al., 2015).

As shown in Table 2 plant length showed that, lines $\mathrm{G}_{5}$ and $\mathrm{G}_{3}$ gave the highest records values respectively, for the first season; while the lines $\mathrm{G}_{1}, \mathrm{G}_{3}, \mathrm{G}_{4}$ gave the highest plant length without significant differences among them during the second season. With respect to number of branches/ plant trait, the recorded data showed that; there was no significant difference among the tested genotypes during the two studying seasons. Flowering date data illustrated that, lines $G_{1}$ and $G_{3}$ recorded the lowest mean values with no significant difference between them during the first season, on the other side, the lines $G_{1}, G_{2}$ and $G_{3}$ recorded the lowest mean values with no significant difference among them along the two seasons. 
Table 2. Mean values of vegetative characters of melon lines recorded during the two growing seasons of 2018 and 2019

\begin{tabular}{|c|c|c|c|c|c|c|c|c|c|}
\hline \multirow{2}{*}{\multicolumn{2}{|c|}{$\begin{array}{c}\text { Season } \\
\text { Salinity } \\
\text { of } \\
\text { irrigation } \\
\text { water } \\
\text { (mg/L) } \\
\end{array}$}} & \multicolumn{4}{|c|}{2018} & \multicolumn{4}{|c|}{2019} \\
\hline & & $\begin{array}{c}\text { plant } \\
\text { length } \\
(\mathrm{cm})\end{array}$ & $\begin{array}{c}\text { No. of } \\
\text { branches/ } \\
\text { plant }\end{array}$ & $\begin{array}{l}\text { Flowering } \\
\text { date (day) }\end{array}$ & $\begin{array}{c}\text { Maturity } \\
\text { date } \\
\text { (day) }\end{array}$ & $\begin{array}{c}\text { plant } \\
\text { length } \\
(\mathrm{cm})\end{array}$ & $\begin{array}{c}\text { No. of } \\
\text { branches/ } \\
\text { Plant }\end{array}$ & $\begin{array}{l}\text { Flowering } \\
\text { date (day) }\end{array}$ & $\begin{array}{c}\text { Maturity } \\
\text { date } \\
\text { (day) }\end{array}$ \\
\hline \multicolumn{10}{|c|}{ Irrigation water salinity levels } \\
\hline \multirow{4}{*}{\multicolumn{2}{|c|}{$\begin{array}{c}500 \mathrm{mg} / \mathrm{L} \\
2000 \\
\mathrm{mg} / \mathrm{L} \\
4000 \\
\mathrm{mg} / \mathrm{L}\end{array}$}} & $223.93^{\mathrm{a}}$ & $4.66^{\mathrm{a}}$ & $48.86^{\mathrm{a}}$ & $90.00^{\mathrm{a}}$ & $236.73^{\mathrm{a}}$ & $4.93^{\mathrm{a}}$ & $46.53^{\mathrm{a}}$ & $90.60^{\mathrm{a}}$ \\
\hline & & $201.60^{\mathrm{ab}}$ & $4.46^{\mathrm{a}}$ & $45.93^{b}$ & $86.26^{\mathrm{a}}$ & $198.66^{\mathrm{b}}$ & $5.00^{\mathrm{a}}$ & $46.53^{\mathrm{a}}$ & $88.40^{\mathrm{a}}$ \\
\hline & & $180.60^{\mathrm{b}}$ & $4.20^{\mathrm{a}}$ & $48.53^{\mathrm{a}}$ & $89.13^{\mathrm{a}}$ & $183.33^{\mathrm{c}}$ & $4.20^{\mathrm{b}}$ & $46.13^{\mathrm{a}}$ & $88.46^{\mathrm{a}}$ \\
\hline & & \multicolumn{8}{|c|}{ Melon lines } \\
\hline \multirow{5}{*}{\multicolumn{2}{|c|}{$\begin{array}{l}\mathrm{G}_{1} \\
\mathrm{G}_{2} \\
\mathrm{G}_{3} \\
\mathrm{G}_{4} \\
\mathrm{G}_{5}\end{array}$}} & $193.66^{\mathrm{bc}}$ & $4.66^{\mathrm{a}}$ & $45.22^{\mathrm{b}}$ & $88.44^{\mathrm{a}}$ & $206.11^{\mathrm{ab}}$ & $4.55^{\mathrm{a}}$ & $43.33^{\mathrm{b}}$ & $89.00^{\mathrm{b}}$ \\
\hline & & $185.00^{c}$ & $4.33^{\mathrm{a}}$ & $48.88^{\mathrm{a}}$ & $87.66^{\mathrm{a}}$ & $192.88^{\mathrm{b}}$ & $5.00^{\mathrm{a}}$ & $44.77^{\mathrm{b}}$ & $88.33^{\mathrm{b}}$ \\
\hline & & $213.44^{\mathrm{ab}}$ & $4.55^{\mathrm{a}}$ & $47.22^{\mathrm{ab}}$ & $87.66^{\mathrm{a}}$ & $211.55^{\mathrm{a}}$ & $4.66^{\mathrm{a}}$ & $44.66^{\mathrm{b}}$ & $85.77^{\mathrm{b}}$ \\
\hline & & $197.22^{\mathrm{bc}}$ & $4.55^{\mathrm{a}}$ & $48.77^{\mathrm{a}}$ & $89.77^{\mathrm{a}}$ & $206.00^{\mathrm{ab}}$ & $4.44^{\mathrm{a}}$ & $48.88^{\mathrm{a}}$ & $89.00^{\mathrm{b}}$ \\
\hline & & $220.88^{a}$ & $4.11^{\mathrm{a}}$ & $48.77^{\mathrm{a}}$ & $88.77^{\mathrm{a}}$ & $214.66^{\mathrm{a}}$ & $4.88^{\mathrm{a}}$ & $50.33^{\mathrm{a}}$ & $93.33^{\mathrm{a}}$ \\
\hline \multicolumn{10}{|c|}{ Irrigation water salinity levels $\mathbf{x}$ Melon lines interactions } \\
\hline \multirow{5}{*}{ 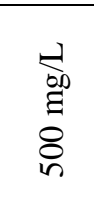 } & $\mathrm{G}_{1}$ & $232.00^{\mathrm{abc}}$ & $4.66^{\mathrm{ab}}$ & $43.33^{\mathrm{d}}$ & $90.66^{\mathrm{ab}}$ & $238.33^{\mathrm{ab}}$ & $5.33^{\mathrm{abc}}$ & $43.66^{\mathrm{d}}$ & $90.66^{\mathrm{a}-\mathrm{d}}$ \\
\hline & $\mathrm{G}_{2}$ & $190.00^{\text {def }}$ & $4.33^{\mathrm{ab}}$ & $51.66^{\mathrm{ab}}$ & $88.00^{\mathrm{abc}}$ & $217.33^{\mathrm{bcd}}$ & $4.66^{\mathrm{a}-\mathrm{e}}$ & $42.66^{\mathrm{d}}$ & $90.33^{\mathrm{a}-\mathrm{d}}$ \\
\hline & $\mathrm{G}_{3}$ & $235.00^{\mathrm{ab}}$ & $4.33^{\mathrm{ab}}$ & $46.66^{\mathrm{cd}}$ & $89.00^{\mathrm{ab}}$ & $250.33^{\mathrm{a}}$ & $5.00^{\mathrm{a}-\mathrm{d}}$ & $46.66^{\mathrm{bcd}}$ & $85.66^{\mathrm{d}}$ \\
\hline & $\mathrm{G}_{4}$ & $220.00^{\mathrm{a}-\mathrm{d}}$ & $5.66^{\mathrm{a}}$ & $49.00^{\mathrm{bc}}$ & $92.00^{\mathrm{a}}$ & $226.66^{\mathrm{abc}}$ & $5.33^{\mathrm{abc}}$ & $49.33^{\mathrm{b}}$ & $92.33^{\mathrm{abc}}$ \\
\hline & $\mathrm{G}_{5}$ & $242.66^{\mathrm{a}}$ & $4.33^{\mathrm{ab}}$ & $53.66^{\mathrm{a}}$ & $90.33^{\mathrm{ab}}$ & $251.00^{\mathrm{a}}$ & $4.33^{\mathrm{b}-\mathrm{e}}$ & $50.66^{\mathrm{ab}}$ & $94.00^{\mathrm{a}}$ \\
\hline \multirow{5}{*}{ 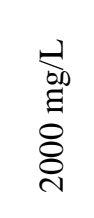 } & $\mathrm{G}_{1}$ & $190.66^{\mathrm{c}-\mathrm{f}}$ & $3.66^{\mathrm{b}}$ & $45.66^{\mathrm{cd}}$ & $83.00^{c}$ & $204.33^{\text {cde }}$ & $5.00^{\mathrm{a}-\mathrm{d}}$ & $43.00^{\mathrm{d}}$ & $89.33^{\mathrm{a}-\mathrm{d}}$ \\
\hline & $\mathrm{G}_{2}$ & $179.00^{\mathrm{def}}$ & $4.33^{\mathrm{ab}}$ & $46.00^{\mathrm{cd}}$ & $87.00^{\mathrm{abc}}$ & $175.00^{\mathrm{e}}$ & $4.66^{\mathrm{a}-\mathrm{e}}$ & $44.66^{\mathrm{cd}}$ & $86.66^{\mathrm{cd}}$ \\
\hline & $\mathrm{G}_{3}$ & $206.66^{\mathrm{a}-\mathrm{e}}$ & $5.00^{\mathrm{ab}}$ & $43.66^{\mathrm{d}}$ & $85.33^{\mathrm{bc}}$ & $208.33^{\mathrm{bcd}}$ & $5.00^{\mathrm{a}-\mathrm{d}}$ & $42.66^{\mathrm{d}}$ & $84.66^{\mathrm{d}}$ \\
\hline & $\mathrm{G}_{4}$ & $195.00^{\mathrm{b}-\mathrm{f}}$ & $4.00^{\mathrm{b}}$ & $49.00^{\mathrm{bc}}$ & $89.33^{\mathrm{ab}}$ & $199.00^{\text {cde }}$ & $4.33^{\mathrm{b}-\mathrm{e}}$ & $48.33^{\mathrm{bc}}$ & $87.66^{\mathrm{bcd}}$ \\
\hline & $\mathrm{G}_{5}$ & $236.66^{\mathrm{ab}}$ & $4.00^{\mathrm{b}}$ & $45.33^{\mathrm{cd}}$ & $86.00^{\mathrm{abc}}$ & $206.66^{\text {cde }}$ & $6.00^{\mathrm{a}}$ & $54.00^{\mathrm{a}}$ & $93.66^{\mathrm{ab}}$ \\
\hline \multirow{5}{*}{$\begin{array}{l}\underset{1}{60} \\
\vdots \\
8 \\
8 \\
8 \\
+\end{array}$} & $\mathrm{G}_{1}$ & $158.33^{f}$ & $5.66^{\mathrm{a}}$ & $46.66^{\mathrm{cd}}$ & $91.66^{\mathrm{a}}$ & $175.66^{\mathrm{e}}$ & $3.33^{\mathrm{e}}$ & $43.66^{\mathrm{d}}$ & $87.00^{\mathrm{cd}}$ \\
\hline & $\mathrm{G}_{2}$ & $186.00^{\text {def }}$ & $4.33^{\mathrm{ab}}$ & $49.00^{\mathrm{bc}}$ & $88.00^{\mathrm{abc}}$ & $186.33^{\text {de }}$ & $5.66^{\mathrm{ab}}$ & $47.00^{\mathrm{bcd}}$ & $89.00^{\mathrm{a}-\mathrm{d}}$ \\
\hline & $\mathrm{G}_{3}$ & $198.66^{\mathrm{b}-\mathrm{f}}$ & $4.33^{\mathrm{ab}}$ & $51.33^{\mathrm{ab}}$ & $88.66^{\mathrm{abc}}$ & $176.00^{\mathrm{e}}$ & $4.00^{\text {cde }}$ & $44.66^{\mathrm{cd}}$ & $87.00^{\mathrm{cd}}$ \\
\hline & $\mathrm{G}_{4}$ & $176.66^{\mathrm{ef}}$ & $4.00^{\mathrm{b}}$ & $48.33^{\mathrm{bc}}$ & $88.00^{\mathrm{abc}}$ & $192.33^{\text {de }}$ & $3.66^{\mathrm{de}}$ & $49.00^{\mathrm{bc}}$ & $87.00^{\mathrm{cd}}$ \\
\hline & $\mathrm{G}_{5}$ & $183.33^{\mathrm{def}}$ & $4.00^{\mathrm{b}}$ & $47.33 b^{c d}$ & $89.33^{\mathrm{ab}}$ & $186.33^{\mathrm{de}}$ & $4.33^{\mathrm{b}-\mathrm{e}}$ & $46.33^{\mathrm{bcd}}$ & $92.33^{\mathrm{abc}}$ \\
\hline
\end{tabular}

Means followed by a similar letter within a column for each parameter is not significantly different at the 0.05 level of probability using Duncan's multiple rang test procedure.

Concerning the interaction between salinity of irrigation water and the tested melon genotypes, Table (2) plant length, number of branches/plant and flowering date were significantly affected $(p \leq 0.05)$. At for the first season, the highest mean value for plant length were recorded by line $\mathrm{G}_{5}$ at $500 \mathrm{mg} / \mathrm{L}$ of water salinity level without significant differences with each of the lines $G_{1}, G_{3}$ and $G_{4}$ at the same level of salinity with lines $G_{3}$ and $G_{5}$ at $2000 \mathrm{mg} / \mathrm{L}$. Results of the second season revealed that line $\mathrm{G}_{5}$ at $500 \mathrm{mg} / \mathrm{L}$ of water salinity level gave the highest plant length with no significant differences with the lines $\mathrm{G}_{1}, \mathrm{G}_{3}$ and $\mathrm{G}_{4}$. -

Concerning number of branches per plant trait Table (2), the data of the first season showed that, line $\mathrm{G}_{4}$ gave the highest mean value with water salinity level of 500 $\mathrm{mg} / \mathrm{L}$ with no significant differences with each of the lines $G_{1}, G_{2}, G_{3}$ and $G_{5}$ at $500 \mathrm{mg} / \mathrm{L}$ of water salinity level; with the lines $\mathrm{G}_{2}$ and $\mathrm{G}_{3}$ at $2000 \mathrm{mg} / \mathrm{L}$ of water salinity level and with each of the lines $G_{1}, G_{2}$ and $G_{3}$ at $4000 \mathrm{mg} / \mathrm{L}$ of water salinity level. Data of the second season showed that the line $\mathrm{G}_{5}$ at $2000 \mathrm{mg} / \mathrm{L}$ of water salinity level gave the highest mean value for number of branches per plant trait without significant differences with each of the lines $\mathrm{G}_{1}, \mathrm{G}_{2}, \mathrm{G}_{3}$ and $\mathrm{G}_{4}$ at $500 \mathrm{mg} / \mathrm{L}$ of water salinity level; with lines $G_{1}, G_{2}$ and $G_{3}$ at 2000 $\mathrm{mg} / \mathrm{L}$ of water salinity level and with the line $\mathrm{G}_{2}$ at 4000 $\mathrm{mg} / \mathrm{L}$ of water salinity level. 
Flowering date data Table (2) showed that, line $\mathrm{G}_{5}$ at $500 \mathrm{mg} / \mathrm{L}$ of water salinity level possessed the highest mean value during the first season with no significant differences with each of the lines $\mathrm{G}_{2}$ at $500 \mathrm{mg} / \mathrm{L}$ of water salinity level and $\mathrm{G}_{4}$ at $4000 \mathrm{mg} / \mathrm{L}$ of water salinity level. Data of the second season showed that line $\mathrm{G}_{5}$ with $500 \mathrm{mg} / \mathrm{L}$ of water salinity level gave the highest mean value for flowering date with no significant differences with the lines $\mathrm{G}_{3}$ and line $\mathrm{G}_{4}$ at $500 \mathrm{mg} / \mathrm{L}$ of water salinity level.

Maturity date showed that the line $\mathrm{G}_{4}$ at $500 \mathrm{mg} / \mathrm{L}$ of water salinity level gave the highest mean value during the first season with no significant differences with most tested melon lines Table (2). Same trend of results were also noted during the second season where the line $\mathrm{G}_{5}$ at $500 \mathrm{mg} / \mathrm{L}$ of water salinity level scored the highest mean value with no significant differences with most tested melon lines. Ibrarullah et al., (2019) reported that for muskmelon, the increasing levels of salt stress substantially decrease the shoot and root biomass, plant height, root length and leaf area in all the genotypes.

\section{Yield and Yield Component Characters:}

Table (3) indicated that melon yield character $[(\mathrm{kg} / \mathrm{plant})$ and average fruit weight/plant $(\mathrm{g})]$ were significantly affected $(p \leq 0.05)$ by the two studied variables melon genotypes and irrigation salinity levels, during the two growing seasons. Respecting to the main effect of irrigation salinity levels, there were significant $(p \leq 0.05)$ and direct proportional relationship between the independent variable (salinity levels) and dependent one (average fruit yield/plant and average fruit weight traits) during the two seasons. Irrigation salinity levels did not affect No. of fruits/plant across the two seasons of this study. The results of the two seasons revealed that increasing water salinity level from 500 up to 4000 $\mathrm{mg} / \mathrm{L}$ had negative effects on both average fruit yield/plant and average fruit weight traits. At $500 \mathrm{mg} / \mathrm{L}$ of salinity level, the highest average values were scored for average fruit yield/plant and average fruit weight/plant. The obtained results showed that the lowest values for the two traits were recorded at 4000 $\mathrm{mg} / \mathrm{L}$ of salinity level during the two study seasons. It is known that the total yield and its components are closely related to the vigorous of vegetative growth. Therefore, the decrease in total yield and its components can be attributed to the fact that the vegetative traits were adversely affected by the high salinity at the irrigation water as shown in Table (2). Abu Muriefah (2015) attributed these results to changes in the osmotic capacity due to the decrease in water content in addition to the specific toxic effects resulting from the accumulation of sodium and chloride ions, as observed in many plants.
As for the main effect of melon genotypes, the recorded data cleared that the line $\mathrm{G}_{3}$ gave the highest mean value for average fruit weight/plant trait without significant differences with line $\mathrm{G}_{4}$ during the first season (Table, 3). Data of the second season showed that line $G_{3}$ gave the highest mean value without significant differences with each of lines $G_{1}, G_{2}$ and $G_{4}$. The results of the first season appeared that the average fruit number did not significantly affect with the tested melon genotypes. The data of the second season showed that line $\mathrm{G}_{4}$ gave the highest mean value for number of fruit/plant trait without significant differences with each of the lines $G_{1}, G_{2}$ and $G_{3}$. The data of the first season showed that line $\mathrm{G}_{4}$ gave the highest mean performance for the average fruit yield/plant character (Table, 3) without significant differences with line $\mathrm{G}_{3}$. With respect to the second study season, the presented data showed that line $G_{4}$ possessed the highest mean value without significant differences with lines $G_{2}$ and $\mathrm{G}_{3}$ (Table 3).

These results agreed with those found by Medeiros et al. (2011) who stated that, regarding number of fruits/plant at salinity values of $0.54 \mathrm{dS} \mathrm{m}^{-1}$, he was found that the increasing of water salinity for the number of fruits, decreasing from 1.59 to 1.29 fruits from the lowest to the highest salinity, A similar action was showed for the total marketable fruit productivity in response to the salinity of the irrigation water. A linear decrease was observed, of $20.31 \%$ and $21.97 \%$ for total yield, respectively, in the level $3.9 \mathrm{dS} \mathrm{m}^{-1}$ in relation to $0.54 \mathrm{dS} \mathrm{m}^{-1}$. These results were similar with Silva et al. (2005) who study different salinity treatments $(1.2 \mathrm{dS}$ $\mathrm{m}^{-1}, 2.5 \mathrm{dS} \mathrm{m}^{-1}$ and $4.4 \mathrm{dS} \mathrm{m}^{-1}$ ), and he found the same results. Medeiros et al., (2008), evaluated the effect of different treatments of water salinity $(1.1,2.5$ and 4.5 $\mathrm{dS} \mathrm{m}^{-1}$ ) and two different hybrids of melon showed a decrease of fruit average because of the salty water. While these results differs from those of Pereira et al., (2017). Who said that, irrigation water salinity does not affect fruit weight, and the reduction in the number of fruits was the main cause of yield reduction of the melon crop under high salinity water. The contents of total soluble solids increased under high salinity level. Giuseppe et al., (2006), found that total yield decreased due to increased salinity in the nutrient solution. The drop in total yield in saline treatments compared to control was due to a drop in the fruit mean and not to the number of fruits/plant.

As shown in Table (3), the interaction between water salinity levels $\times$ melon lines was significant regarding most studied characters during the two seasons, except for number of fruits / plant during the first season. 
Table 3. Mean values of yield and its components characteristics of melon lines recorded during the growing seasons of 2018 and 2019

\begin{tabular}{|c|c|c|c|c|c|c|c|}
\hline \multirow{2}{*}{\multicolumn{2}{|c|}{$\begin{array}{c}\text { Seasons } \\
\text { Salinity of } \\
\text { irrigation } \\
\text { water }(\mathrm{mg} / \mathrm{L})\end{array}$}} & \multicolumn{3}{|c|}{2018} & \multicolumn{3}{|c|}{2019} \\
\hline & & $\begin{array}{c}\text { Average } \\
\text { fruit weight } \\
(\mathrm{g})\end{array}$ & $\begin{array}{c}\text { No. of } \\
\text { fruits/ } \\
\text { plant }\end{array}$ & $\begin{array}{c}\text { Total yield } \\
\text { (kg)/ } \\
\text { Plant }\end{array}$ & $\begin{array}{c}\text { average } \\
\text { fruit } \\
\text { weight } /(\mathrm{g})\end{array}$ & $\begin{array}{l}\text { No. of } \\
\text { fruits/ } \\
\text { Plant }\end{array}$ & $\begin{array}{c}\text { Total yield }(\mathrm{kg}) / \\
\text { Plant }\end{array}$ \\
\hline \multicolumn{8}{|c|}{ Irrigation water salinity levels } \\
\hline \multirow{3}{*}{\multicolumn{2}{|c|}{$\begin{array}{c}500 \mathrm{mg} / \mathrm{L} \\
2000 \mathrm{mg} / \mathrm{L} \\
4000 \mathrm{mg} / \mathrm{L}\end{array}$}} & $920.66^{\mathrm{a}}$ & $4.20^{\mathrm{a}}$ & $3.73^{\mathrm{a}}$ & $902.00^{\mathrm{a}}$ & $4.13^{\mathrm{a}}$ & $3.71^{\mathrm{a}}$ \\
\hline & & $703.33^{\mathrm{b}}$ & $4.13^{\mathrm{a}}$ & $2.94^{\mathrm{b}}$ & $697.33^{\mathrm{b}}$ & $4.20^{\mathrm{a}}$ & $2.94^{\mathrm{b}}$ \\
\hline & & $606.00^{\mathrm{c}}$ & $4.06^{\mathrm{a}}$ & $2.53^{\mathrm{b}}$ & $606.66^{\mathrm{c}}$ & $4.06^{\mathrm{a}}$ & $2.47^{\mathrm{c}}$ \\
\hline \multicolumn{8}{|c|}{ Melon lines } \\
\hline \multicolumn{2}{|c|}{$\mathrm{G}_{1}$} & $694.44^{c}$ & $3.88^{\mathrm{a}}$ & $2.71^{b c}$ & $707.77^{\mathrm{ab}}$ & $3.88^{\mathrm{ab}}$ & $2.72^{\mathrm{b}}$ \\
\hline \multicolumn{2}{|c|}{$\mathrm{G}_{2}$} & $715.55^{\mathrm{bc}}$ & $4.11^{\mathrm{a}}$ & $2.92^{b c}$ & $726.66^{\mathrm{ab}}$ & $4.11^{\mathrm{ab}}$ & $2.97^{\mathrm{ab}}$ \\
\hline \multicolumn{2}{|c|}{$\mathrm{G}_{3}$} & $850.00^{\mathrm{a}}$ & $4.11^{\mathrm{a}}$ & $3.43^{\mathrm{ab}}$ & $795.00^{\mathrm{a}}$ & $4.33^{\mathrm{ab}}$ & $3.45^{\mathrm{a}}$ \\
\hline \multicolumn{2}{|c|}{$\mathrm{G}_{4}$} & $791.11^{\mathrm{ab}}$ & $4.66^{\mathrm{a}}$ & $3.73^{\mathrm{a}}$ & $776.33^{\mathrm{a}}$ & $4.55^{\mathrm{a}}$ & $3.57^{\mathrm{a}}$ \\
\hline \multirow{2}{*}{\multicolumn{2}{|c|}{$\mathrm{G}_{5}$}} & $665.55^{\mathrm{c}}$ & $3.88^{\mathrm{a}}$ & $2.53^{\mathrm{c}}$ & $671.11^{\mathrm{b}}$ & $3.77^{\mathrm{b}}$ & $2.50^{\mathrm{b}}$ \\
\hline & & \multicolumn{6}{|c|}{ Irrigation water salinity levels $x$ Melon lines interactions } \\
\hline \multirow{5}{*}{ 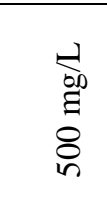 } & $\mathrm{G}_{1}$ & $883.33^{\mathrm{bc}}$ & $4.00^{\mathrm{ab}}$ & $3.55^{\mathrm{bc}}$ & $916.66^{\mathrm{ab}}$ & $3.66^{\mathrm{a}}$ & $3.33^{\mathrm{a}-\mathrm{e}}$ \\
\hline & $\mathrm{G}_{2}$ & $880.00^{\mathrm{bc}}$ & $4.00^{\mathrm{ab}}$ & $3.52^{\mathrm{bc}}$ & $970.00^{\mathrm{a}}$ & $4.00^{\mathrm{a}}$ & $3.88^{\mathrm{ab}}$ \\
\hline & $\mathrm{G}_{3}$ & $1100.00^{\mathrm{a}}$ & $3.66^{\mathrm{b}}$ & $3.96^{\mathrm{ab}}$ & $905.00^{\mathrm{ab}}$ & $4.33^{\mathrm{a}}$ & $3.91^{\mathrm{ab}}$ \\
\hline & $\mathrm{G}_{4}$ & $940.00^{\mathrm{b}}$ & $5.33^{\mathrm{a}}$ & $5.00^{\mathrm{a}}$ & $903.33^{\mathrm{ab}}$ & $5.00^{\mathrm{a}}$ & $4.51^{\mathrm{a}}$ \\
\hline & $\mathrm{G}_{5}$ & $800.00^{\mathrm{bcd}}$ & $3.33^{b}$ & $2.63^{\mathrm{bcd}}$ & $815.66^{\mathrm{abc}}$ & $3.66^{\mathrm{a}}$ & $2.93^{\mathrm{b}-\mathrm{e}}$ \\
\hline \multirow{5}{*}{ 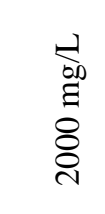 } & $\mathrm{G}_{1}$ & $616.66^{\mathrm{de}_{\mathrm{f}}}$ & $4.33^{\mathrm{ab}}$ & $2.66^{\mathrm{bcd}}$ & $656.66^{\text {cde }}$ & $4.00^{\mathrm{a}}$ & $2.62^{\text {cde }}$ \\
\hline & $\mathrm{G}_{2}$ & $683.33^{\mathrm{def}}$ & $4.00^{\mathrm{ab}}$ & $2.70^{\mathrm{bcd}}$ & $623.33^{\mathrm{de}}$ & $4.66^{\mathrm{a}}$ & $2.9^{\mathrm{b}-\mathrm{e}}$ \\
\hline & $\mathrm{G}_{3}$ & $733.33^{\text {cde }}$ & $4.33^{\mathrm{ab}}$ & $3.16^{\mathrm{bcd}}$ & $780.00^{\mathrm{bcd}}$ & $4.33^{\mathrm{a}}$ & $3.45^{\mathrm{abc}}$ \\
\hline & $\mathrm{G}_{4}$ & $816.66^{\text {bcd }}$ & $4.33^{\mathrm{ab}}$ & $3.53^{\mathrm{bc}}$ & $780.00^{\mathrm{bcd}}$ & $4.33^{\mathrm{a}}$ & $3.39^{\mathrm{a}-\mathrm{d}}$ \\
\hline & $\mathrm{G}_{5}$ & $666.66^{\text {def }}$ & $4.00^{\mathrm{ab}}$ & $2.66 b^{c d}$ & $643.33^{\mathrm{de}}$ & $3.66^{\mathrm{a}}$ & $2.36^{\mathrm{cde}}$ \\
\hline \multirow{5}{*}{ 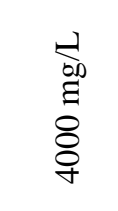 } & $\mathrm{G}_{1}$ & $583.33^{\mathrm{ef}}$ & $3.33^{\mathrm{b}}$ & $2.00^{\mathrm{d}}$ & $550.00^{\mathrm{e}}$ & $4.00^{\mathrm{a}}$ & $2.20^{\mathrm{de}}$ \\
\hline & $\mathrm{G}_{2}$ & $583.33^{\mathrm{ef}}$ & $4.33^{\mathrm{ab}}$ & $2.56^{\mathrm{bcd}}$ & $586.66^{\mathrm{e}}$ & $3.66^{\mathrm{a}}$ & $2.14^{\mathrm{e}}$ \\
\hline & $\mathrm{G}_{3}$ & $716.66 d^{e}$ & $4.33^{\mathrm{ab}}$ & $3.18^{\mathrm{bcd}}$ & $696.66^{\mathrm{cde}}$ & $4.33^{\mathrm{a}}$ & $3.00^{\mathrm{b}-\mathrm{e}}$ \\
\hline & $\mathrm{G}_{4}$ & $616.66^{\mathrm{ef}}$ & $4.33^{\mathrm{ab}}$ & $2.68^{\mathrm{bcd}}$ & $646.66^{\mathrm{de}}$ & $4.33^{\mathrm{a}}$ & $2.80^{\mathrm{b}-\mathrm{e}}$ \\
\hline & $\mathrm{G}_{5}$ & $530.00^{\mathrm{f}}$ & $4.33^{\mathrm{ab}}$ & $2.30^{\mathrm{cd}}$ & $553.33^{\mathrm{e}}$ & $4.00^{\mathrm{a}}$ & $2.20^{\mathrm{de}}$ \\
\hline
\end{tabular}

Means followed by a similar letter within a column for each parameter is not significantly different at the 0.05 level of probability using Duncan's multiple rang test procedure.

These results indicated that the best mean values for the studied characters (yield and its component characteristics) were achieved when the tested melon lines were grown at a salinity level of $500 \mathrm{mg} / \mathrm{L}$. The lowest averages were recorded when any of the tested melon lines were grown at a salinity level of 4000 $\mathrm{mg} / \mathrm{L}$.

\section{Performances of Fruit Characteristics:}

The mean values of the economic fruit characters of the 5 lines for water salinity concentration and salinity lines interaction were shown in( Table 4) which clearly showed that fruit shape index, total soluble solids (TSS) and fruit moisture content trait were significantly affected by different levels of saline water irrigation during the first season. Results of the second season showed that, each of total soluble solids and fruit moisture content traits were significantly affected by different levels of salinity during the second season.

Table (4) also clearly showed that there were significant differences among the tested melon genotypes regarding the most studied fruit characteristics except for fruit netting degree during the first study season. This result clearly indicated that the evaluated melon lines differed in their genetic potential regarding to its chemical compositions. The data of the second season showed that only skin color and total soluble solids traits possessed significant differences among the tested melon lines. These significant differences indicated that the evaluated melon lines differed in their genetic potential regarding to its fruit characteristics. In this respect, the data of the first 
Table 4. Mean values of fruit characteristics of melon lines recorded during the two growing seasons of 2018 and 2019

\begin{tabular}{|c|c|c|c|c|c|c|c|c|c|c|c|}
\hline \multirow{2}{*}{\multicolumn{2}{|c|}{$\begin{array}{c}\text { Seasons } \\
\text { Salinity of } \\
\text { rrigation water } \\
(\mathrm{mg} / \mathrm{L})\end{array}$}} & \multicolumn{5}{|c|}{2018} & \multicolumn{5}{|c|}{2019} \\
\hline & & $\begin{array}{c}\text { Fruit } \\
\text { netting } \\
\text { degree }\end{array}$ & $\begin{array}{l}\text { Fruit } \\
\text { shape } \\
\text { index }\end{array}$ & $\begin{array}{l}\text { Skin } \\
\text { color }\end{array}$ & T.S.S & $\begin{array}{l}\text { Moisture } \\
\text { content \% }\end{array}$ & $\begin{array}{c}\text { Fruit } \\
\text { netting } \\
\text { degree }\end{array}$ & $\begin{array}{l}\text { Fruit } \\
\text { shape } \\
\text { index }\end{array}$ & $\begin{array}{l}\text { Skin } \\
\text { color }\end{array}$ & T.S.S & $\begin{array}{l}\text { Moisture } \\
\text { content \% }\end{array}$ \\
\hline \multicolumn{12}{|c|}{ Irrigation water salinity levels } \\
\hline & $\mathrm{ng} / \mathrm{L}$ & $8.93^{\mathrm{a}}$ & $0.93^{\mathrm{a}}$ & $9.00^{\mathrm{a}}$ & $12.35^{\mathrm{b}}$ & $94.07^{\mathrm{a}}$ & $8.93^{\mathrm{a}}$ & $0.94^{\mathrm{a}}$ & $9.40^{\mathrm{a}}$ & $12.97^{\mathrm{b}}$ & $94.65^{\mathrm{a}}$ \\
\hline & $\mathrm{ng} / \mathrm{L}$ & $9.26^{\mathrm{a}}$ & $0.95^{\mathrm{b}}$ & $8.86^{\mathrm{a}}$ & $13.09^{\mathrm{ab}}$ & $91.41^{\mathrm{b}}$ & $8.00^{\mathrm{a}}$ & $0.98^{\mathrm{a}}$ & $8.93^{\mathrm{a}}$ & $13.62^{\mathrm{ab}}$ & $91.82^{\mathrm{b}}$ \\
\hline & $n g / L$ & $8.53^{\mathrm{a}}$ & $1.00^{\mathrm{a}}$ & $8.46^{\mathrm{a}}$ & $14.30^{\mathrm{a}}$ & $90.02^{\mathrm{c}}$ & $8.86^{\mathrm{a}}$ & $0.97^{\mathrm{a}}$ & $8.73^{\mathrm{a}}$ & $14.10^{\mathrm{a}}$ & $90.87^{\mathrm{b}}$ \\
\hline \multicolumn{12}{|c|}{ Melon lines } \\
\hline & & $7.33^{\mathrm{b}}$ & $1.01^{\mathrm{a}}$ & $7.66^{\mathrm{b}}$ & $13.25^{\mathrm{ab}}$ & $92.97^{\mathrm{a}}$ & $8.77^{\mathrm{ab}}$ & $0.97^{\mathrm{a}}$ & $9.22^{\mathrm{ab}}$ & $12.85^{\mathrm{b}}$ & $92.37^{\mathrm{a}}$ \\
\hline & & $9.66^{\mathrm{a}}$ & $0.95^{\mathrm{a}}$ & $8,22^{\mathrm{ab}}$ & $13.35^{\mathrm{ab}}$ & $92.10^{\mathrm{ab}}$ & $9.11^{\mathrm{a}}$ & $0.96^{\mathrm{a}}$ & $9.00^{\mathrm{ab}}$ & $13.76^{\mathrm{ab}}$ & $3.07^{\mathrm{a}}$ \\
\hline & & $9.00^{\mathrm{a}}$ & $0.98^{\mathrm{a}}$ & $8.88^{\mathrm{ab}}$ & $13.58^{\mathrm{a}}$ & $91.55^{\mathrm{ab}}$ & $9.22^{\mathrm{a}}$ & $0.94^{\mathrm{a}}$ & $9.00^{\mathrm{ab}}$ & $13.58^{\mathrm{ab}}$ & $92.16^{\mathrm{a}}$ \\
\hline & & $9.44^{\mathrm{a}}$ & $0.92^{\mathrm{a}}$ & $9.77^{\mathrm{a}}$ & $13.74^{\mathrm{a}}$ & $90.66^{\mathrm{b}}$ & $8.44^{\mathrm{ab}}$ & $0.99^{\mathrm{a}}$ & $9.55^{\mathrm{a}}$ & $14.11^{\mathrm{a}}$ & $91.86^{\mathrm{a}}$ \\
\hline & & $9.11^{\mathrm{a}}$ & $0.95^{\mathrm{a}}$ & $9.33^{\mathrm{a}}$ & $12.30^{\mathrm{b}}$ & $91.89^{\mathrm{ab}}$ & $7.44^{\mathrm{b}}$ & $0.96^{\mathrm{a}}$ & $8.33^{\mathrm{b}}$ & $13.51^{\mathrm{ab}}$ & $92.78^{a}$ \\
\hline \multicolumn{12}{|c|}{ Irrigation water salinity levels $\mathbf{x}$ Melon lines interactions } \\
\hline \multirow{5}{*}{ 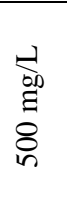 } & $\mathrm{G}_{1}$ & $8.00^{\mathrm{ab}}$ & $0.85^{\mathrm{de}}$ & $8.66^{\mathrm{abc}}$ & $12.1^{\mathrm{bc}}$ & $94.52^{\mathrm{ab}}$ & $8.66^{\mathrm{a}-\mathrm{d}}$ & $1.00^{\mathrm{ab}}$ & $8.66^{\mathrm{abc}}$ & $12.16^{\mathrm{c}}$ & $94.15^{\mathrm{ab}}$ \\
\hline & $\mathrm{G}_{2}$ & $9.33^{\mathrm{a}}$ & $0.89^{\mathrm{cd}}$ & $9.00^{\mathrm{ab}}$ & $12.66^{\mathrm{ab}}$ & $93.02^{\mathrm{abc}}$ & $9.33^{\mathrm{abc}}$ & $0.92^{\mathrm{ab}}$ & $9.66^{\mathrm{a}}$ & $13.40^{\mathrm{abc}}$ & $93.84^{\mathrm{abc}}$ \\
\hline & $\mathrm{G}_{3}$ & $8.00^{\mathrm{ab}}$ & $0.93^{\mathrm{a}-\mathrm{d}}$ & $8.00^{\mathrm{abc}}$ & $13.33^{\mathrm{ab}}$ & $93.99^{\mathrm{ab}}$ & $10.00^{\mathrm{a}}$ & $0.94^{\mathrm{ab}}$ & $10.00^{\mathrm{a}}$ & $13.20^{\mathrm{abc}}$ & $94.86^{\mathrm{a}}$ \\
\hline & $\mathrm{G}_{4}$ & $10.00^{\mathrm{a}}$ & $1.03^{\mathrm{abc}}$ & $10.00^{\mathrm{a}}$ & $13.00^{\mathrm{ab}}$ & $93.97^{\mathrm{ab}}$ & $9.66^{\mathrm{ab}}$ & $0.94^{\mathrm{ab}}$ & $10.00^{\mathrm{a}}$ & $13.26^{\mathrm{abc}}$ & $95.21^{\mathrm{a}}$ \\
\hline & $\mathrm{G}_{5}$ & $9.33^{\mathrm{a}}$ & $0.94^{\mathrm{a}-\mathrm{d}}$ & $9.33^{\mathrm{ab}}$ & $10.66^{\mathrm{c}}$ & $94.85^{\mathrm{a}}$ & $7.00^{\mathrm{cd}}$ & $0.93^{\mathrm{ab}}$ & $8.66^{\mathrm{abc}}$ & $12.82^{\mathrm{bc}}$ & $95.18^{a}$ \\
\hline \multirow{5}{*}{ 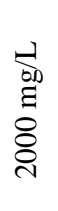 } & $\mathrm{G}_{1}$ & $8.66^{\mathrm{a}}$ & $1.07^{\mathrm{ab}}$ & $8.33^{\mathrm{abc}}$ & $13.00^{\mathrm{ab}}$ & $92.49^{\mathrm{abc}}$ & $8.00^{\mathrm{a}-\mathrm{d}}$ & $0.97^{\mathrm{ab}}$ & $9.66^{\mathrm{a}}$ & $13.53^{\mathrm{ab}}$ & $91.92^{\mathrm{b}-\mathrm{e}}$ \\
\hline & $\mathrm{G}_{2}$ & $10.00^{\mathrm{a}}$ & $0.96^{\mathrm{a}-\mathrm{d}}$ & $7.00^{\mathrm{bc}}$ & $13.10^{\mathrm{ab}}$ & $92.81^{\mathrm{abc}}$ & $9.33^{\mathrm{abc}}$ & $1.02^{\mathrm{a}}$ & $9.00^{\mathrm{ab}}$ & $13.43^{\mathrm{abc}}$ & $93.42^{\mathrm{a}-\mathrm{d}}$ \\
\hline & $\mathrm{G}_{3}$ & $9.33^{\mathrm{a}}$ & $1.08^{\mathrm{ab}}$ & $9.66^{\mathrm{ab}}$ & $13.00^{\mathrm{ab}}$ & $91.17^{\text {cde }}$ & $7.66^{\mathrm{a}-\mathrm{d}}$ & $0.90^{\mathrm{b}}$ & $7.00^{c}$ & $13.00^{\mathrm{abc}}$ & $91.39^{\text {cde }}$ \\
\hline & $\mathrm{G}_{4}$ & $9.33^{\mathrm{a}}$ & $0.70^{\mathrm{e}}$ & $10.00^{\mathrm{a}}$ & $13.73^{\mathrm{ab}}$ & $89.44^{\mathrm{de}}$ & $8.33^{\mathrm{a}-\mathrm{d}}$ & $1.02^{\mathrm{a}}$ & $10.00^{\mathrm{a}}$ & $14.30^{\mathrm{ab}}$ & $90.90^{\mathrm{de}}$ \\
\hline & $\mathrm{G}_{5}$ & $9.00^{\mathrm{a}}$ & $0.94^{\mathrm{a}-\mathrm{d}}$ & $9.33^{\mathrm{ab}}$ & $12.63^{\mathrm{ab}}$ & $91.16^{\text {cde }}$ & $6.66^{\mathrm{d}}$ & $0.98^{\mathrm{ab}}$ & $9.00^{\mathrm{ab}}$ & $13.83^{\mathrm{abc}}$ & $91.50^{\text {cde }}$ \\
\hline \multirow{5}{*}{$\begin{array}{l}\underbrace{}_{00} \\
\vdots \\
8 \\
8 \\
8\end{array}$} & $\mathrm{G}_{1}$ & $5.33^{\mathrm{b}}$ & $1.11^{\mathrm{a}}$ & $6.00^{\mathrm{c}}$ & $14.66^{\mathrm{a}}$ & $91.91^{\text {bcd }}$ & $9.66^{\mathrm{ab}}$ & $0.96^{\mathrm{ab}}$ & $9.33^{\mathrm{a}}$ & $12.86^{\mathrm{bc}}$ & $91.03^{\mathrm{de}}$ \\
\hline & $\mathrm{G}_{2}$ & $9.66^{\mathrm{a}}$ & $1.01^{\mathrm{abcd}}$ & $8.66^{a b} c$ & $14.30^{\mathrm{a}}$ & $90.47^{\text {cde }}$ & $8.66^{\mathrm{a}-\mathrm{d}}$ & $0.96^{\mathrm{ab}}$ & $8.33^{\mathrm{abc}}$ & $14.46^{\mathrm{ab}}$ & $91.95^{\text {b-e }}$ \\
\hline & $\mathrm{G}_{3}$ & $9.66^{\mathrm{a}}$ & $0.92^{\mathrm{bcd}}$ & $9.00^{\mathrm{ab}}$ & $14.43^{\mathrm{a}}$ & $89.50^{\mathrm{de}}$ & $10.00^{\mathrm{a}}$ & $0.99^{\mathrm{ab}}$ & $10.00^{\mathrm{a}}$ & $14.56^{\mathrm{ab}}$ & $90.25^{\mathrm{e}}$ \\
\hline & $\mathrm{G}_{4}$ & $9.00^{\mathrm{a}}$ & $1.03^{\mathrm{abc}}$ & $9.33^{\mathrm{ab}}$ & $14.50^{\mathrm{a}}$ & $88.56^{\mathrm{e}}$ & $7.33^{\mathrm{bcd}}$ & $1.00^{\mathrm{ab}}$ & $8.66^{\mathrm{abc}}$ & $14.76^{\mathrm{a}}$ & $89.48^{\mathrm{e}}$ \\
\hline & $\mathrm{G}_{5}$ & $9.00^{\mathrm{a}}$ & $0.97^{\mathrm{a}-\mathrm{d}}$ & $9.33^{\mathrm{ab}}$ & $13.6^{\mathrm{ab}}$ & $89.66 \mathrm{~d}^{\mathrm{e}}$ & $8.66^{\mathrm{a}-\mathrm{d}}$ & $0.96^{\mathrm{ab}}$ & $7.33^{\mathrm{bc}}$ & $13.83^{\mathrm{abc}}$ & $91.66^{\text {cde }}$ \\
\hline
\end{tabular}

Means followed by a similar letter within a column for each parameter is not significantly different at the 0.05 level of probability using Duncan's multiple rang test procedure.

season showed that line $\mathrm{G}_{2}$ gave the highest mean value for fruit netting degree trait without significant differences with most tested lines during the first season. On the other hand, the line $\mathrm{G}_{3}$ gave the highest mean value for the previous trait without significant differences with most tested lines during the second study season. Regarding skin color and total soluble solids traits, the data of the two study seasons showed that; line $\mathrm{G}_{4}$ gave the highest mean performances in this respect without significant differences with most tested lines. The results for fruit moisture content demonstrated that the line $G_{1}$ gave the highest mean value without significant differences with most tested lines during the first study season.

As shown in Table (4), the interaction between water salinity levels $\times$ melon lines was significant regarding the studied fruit characteristics during the two study seasons. The line $\mathrm{G}_{4}$ recorded the highest value for the fruit netting degree with the water salinity $500 \mathrm{mg} / \mathrm{L}$ with no significant difference with 2000 and $4000 \mathrm{mg} / \mathrm{L}$ concentration, the same results was recorded by line $\mathrm{G}_{3}$ and line $\mathrm{G}_{4}$ in the second season.

For fruit shape index the obtained data show that, line $G_{1}$ and line $G_{2}$ recorded the lowest values when the water salinity was $500 \mathrm{mg} / \mathrm{L}$ followed by line $\mathrm{G}_{3}$ when the water salinity was $4000 \mathrm{mg} / \mathrm{L}$, but for the others there is no significant differences among them in the first season. But in the second season there are no significant differences except for line $\mathrm{G}_{3}$ when the water salinity was $2000 \mathrm{mg} / \mathrm{L}$.

Concerning fruit skin color, the obtained data recorded salinity 500 and $2000 \mathrm{mg} / \mathrm{L}$; there is no significant differences among the tested genotypes except for line $\mathrm{G}_{2}$ at $2000 \mathrm{mg} / \mathrm{L}$, but at $4000 \mathrm{mg} / \mathrm{L}$ 
line $\mathrm{G}_{1}$ recorded the lowest value. On the other side, the data for the second season recorded no significant differences among all the concentration of water salinity for all genotypes except for line $\mathrm{G}_{3}$ at $2000 \mathrm{mg} / \mathrm{L}$ and line $\mathrm{G}_{5}$ at $4000 \mathrm{mg} / \mathrm{L}$ with no significant differences among them (Table 4).

For T.S.S, $\mathrm{G}_{1}$ recorded the highest value with no significant differences with the other genotypes for all the water salinity concentration except for line $G_{1}$ and $\mathrm{G}_{5}$ with the water salinity $500 \mathrm{mg} / \mathrm{L}$ for the first season. On the other hand $\mathrm{G}_{4}$ recorded the highest value for TSS with no significant differences with the other genotypes except for $G_{1}$ at $4000 \mathrm{mg} / \mathrm{L}$ and $G_{1}$ and $G_{5}$ at $500 \mathrm{mg} / \mathrm{L}$ (Table 4).

For moisture content; $\mathrm{G}_{4}$ recorded the lowest value in the two seasons at $4000 \mathrm{mg} / \mathrm{L}$, but the highest value was recorded by $G_{5}$ in the first season and $G_{4}(95.21)$ in second season at $500 \mathrm{mg} / \mathrm{L}$. Theses results are in agreement with Sivritepe et al (2003) who showing the same elevated values in the dry matter production at all salinity levels under study. According to Giuseppe et al (2006), salinity improved fruit quality by increasing dry matter (DM), glucose and total soluble solid (TSS) content. Akrami and Arzani (2019) reported that, fruit physical and chemical quality traits were influenced by salinity stress such that fruit size and pulp percentage decreased but fruit peel thickness and sweetness increased.

\section{CONCLUSIONS}

The investigation goal is to expand melon crop cultivation through horizontal expansion in areas that are irrigated with saline water while maintaining access to an economical crop of high quality. From the obtained results the lines $\mathrm{G}_{3}$ and $\mathrm{G}_{4}$ showed the highest tolerance to the saline water irrigation $(2000,4000$ $\mathrm{mg} / \mathrm{L}$ ), so we recommend to use these lines either in areas irrigated with saline water or to be integrated in breeding program to produce more salt tolerant hybrid of melon plant that can be used in cultivating areas irrigated with saline water.

\section{REFERENCES}

Abu-Muriefah, S. S. 2015. Effect of sitosterol on growth, metabolism and protein pattern of pepper (Capsicum annuиm L) plants grown under salt stress conditions. Int. J. Agric. Sci., 8(2): 94- 106.

Akrami, M. and A. Ahmad. 2019. Inheritance of fruit yield and quality in melon (Cucumis melo L.) grown under field salinity stress. Sci. Reports 9:7249

Aragao, C. A., J. S. Santos, S. O. P. Queiroz and B. França. 2009. Avaliação de cultivares de melao sob condições de estresse salino. Revista Caatinga, 22: 161-169.
Arzani, A. and M. Ashraf. 2016. Smart engineering of genetic resources for enhanced salinity tolerance in crop plants. Crit. Rev. Plant Sci.35:146-189.

Badr M.A. and S.D. Abou Hussein. 2008. Yield and fruit quality of drip-irrigated cantaloupe under salt stress conditions in an arid environment. Australian J. Basic Applied Sci., 2(1): 141-148.

Bhaskar, G. and H. Bingru. 2014. Mechanism of salinity tolerance in plants: physiological, biochemical, and molecular characterization. International J. Genomics. Article ID 701596, 18 pages

Botía P.J.M., A. Navarro _V. Cerdá and A. Martínez. 2006. Yield and fruit quality of two melon cultivars irrigated with saline water at different stages of development. European J. Agron. 23: 243-253.

Colla G., Y. Rouphael, _M. Cardarelli, D. Massa, A. Salerno and E. Rea.2006. Yield, fruit quality and mineral composition of grafted melon plants grown under saline conditions. J. Hort. Sci. Biotec. 81: 146-152.

Dasgan H.Y. and S. Koc. 2009.Evaluation of salt tolerance in common bean genotypes by ion regulation and searching for screening parameters. J. Food Agric. Environ., 7(2): 363-372.

Dias, N. da S., A. M. de Oliveira, O. N. de Sousa Neto, F.F. Blanco and J. R. L. Rebouças, Concentração salina e fases de exposição à salinidade do meloeiro cultivado em substrato de fibra de coco. Revista Brasileira de Fruticultura, v.33, p.915-921, 2011. https://doi.org/10.1590/S0100-29452011005000084

Engenharia Agrícola, v.34, p.649-659, 2014. https://doi.org/10.1590/S0100-69162014000400005

Ertan Y., T. Metin and G. Ismail. 2008. Effect of foliar salicylic acid applications on growth, chlorophyll, and mineral content of cucumber grown under salt stress. $\underline{J}$. Plant Nutrit. 31: 593-612.

Eslamboly, A. A. and M. A. S. Abdel-Wahab.2014. Grafting salinity tolerant rootstocks and magnetic iron treatments for cantaloupe production under conditions of high salinity soil and irrigation water. Middle East J. Agri. Res. 3(3): 677-693, ISSN 2077-4605

Fahad, S., S. Hussain, A. Matloob, F. A. Khan, A. Khaliq, S. Saud and M. Faiq.2015. Phytohormones and plant responses to salinity stress: a review. Pl. Grow. Regul., 75: 391-404.

Firdes, U., A. Alim, U. Abdullah, and Y. Halit.2019.Grafting for sustainable growth performance of melon (Cucumis melo) under salt stressed hydroponic condition. European J. Sustainable Development, 8, 1:201-210

Francisco A. de L. Pereira, F. de M. José, R. G. Hans, da S. D. Nildo , P. Welka and B. e L. V. Cybelle.2017.Tolerance of melon cultivars to irrigation water salinity, agriambi v.21, n.12, p.846-851

Gee, G. W. and J. W. Bauder.1986. Particle-size analysis. Part 1- Physical and mineralogical methods. In: "Methods of soil analysis", (ed.): Klute, A., Second Edition, Agronomy No.9, America Society of Agronomy, Inc. Soil Sci. Soc. Amer., Madison, Wisconsin, USA, PP.381-411. 
Giuseppe, C., R. Youssef. and T. C. Maria . 2006. Effect of salinity on yield, fruit quality, leaf gas exchange, and mineral composition of grafted watermelon plants. HortScience: a publication of the American Society for Horticultural Science 41(3):622-627

https://www.agric.wa.gov.au/water-management/watersalinity-and-plant-irrigation.

Ibrarullah, Ur R. Habib, S. J. Muhammad, R. G. Ali, and U. Kalim. 2019. Tolerance response of muskmelon genotypes against salinity. Pak. J. Agri. Sci., 56(1): 63-70

Khan, M.J., H. Rashid, and R. Ali. 1999.Inter-varietal variability in wheat grown under saline conditions. Pak. J. Biol. Sci., 2: 693-696.

Lopez, C.M.L., H. Takahashi, and S. Yamazaki.2002.Plantwater relations of kidney bean plants treated with $\mathrm{NaCl}$ and foliarly applied glycinebetaine. J. Agron. Crop Sci., 188: 73-80.

Maas, E.V. and S.R. Grattan.1999. Crop Yields as Affected by Salinity. In: Skaggs, R.W. and van Schilf gaarde, J., Eds., Agricultural Drainage Agronomy Monograph No. 38, ASA, Madison: 55-108.

Mangal, J. L., P. S. Hooda, and S. Lal.1988. Salt tolerance in five muskmelon cultivars. J. Agr. Sci., 110: 641-643.

Medeiros, D.C., J.F. Medeiros, F.A.L. Pereira, S.C.M. Silva and M.G. Amâncio. 2011.Production and quality of melon hybrid Mandacaru irrigated with different levels of salinity. Horticultura Brasileira 29: 600-604.

Medeiros, J. F. de, C. P. C.Terceiro Neto, H. R. Gheyi, N. da S. Dias, M. S. de M. Souza and R. O. de Souza. 2014. Management strategies of saline water on morphometric characteristics of melon cultivars.

Medeiros, J.F., N.S. Dias and A.D. Barros.2008. Manejo da irrigação e tolerância do meloeiro a salinidade da água de irrigação. Revista Brasileira Ciências Agrárias 3: 242-247.

Meiri, A. and Z. Plaut. 1981.Salt tolerance of glasshouse grown muskmelon. Soil Sci. 131: 189-193.

Mendlinger, S. and D. Pasternak. 2015.Effect of time of Stalinization on flowering, yield and fruit quality factors in melon, Cucumis melo L. J. of Hort. Sci. 67: 529-534.

Mendlinger, S. and D. Pasternak.1992.Screening for salt tolerance in melons. Hort Sci., 27(8): 905-907.

Nangare, D. D., K. G. Singh and S. Kumar. 2013. Effect of blending fresh-saline water and discharge rate of drip on plant yield, water use efficiency (WUE) and quality of tomato in semi-arid environment. African Journal of agricultural Research, v.8, p.3639-3645, https://doi.org/10.5897/AJAR12.168
Nukaya, A., M. Masui and A. Ishida.1980. Salt tolerance of muskmelons grown in different salinity soils (in Japanese with English abstract) J. Japan. Soc. Hort. Sci., 48: 468474.

Page, A. L., R. H. Miller and D. R. Keeney.1982. Methods of soil analysis, Part 2: Chem. and Microbiological Properties. Am. Soc. Agron., Madison, Wisconsin, U.S.A.

Pereira, F.A.L., J.F. Medeiros, H.R. Gheyi, N.S. Dias, W. Preston and C.B.L. Vasconcelos.2017. Tolerance of melon cultivars to irrigation water salinity. Rev. Bras. Eng. Agríe . Amb . 21(12):846-851.

Rahimi, R., A. Mohammakhani, V. Roohi and N. Armand.2012.Effects of salt stress and silicon nutrition on cholorophyll content, yield and yield components in fennel (Foeniculum vulgar Mill.). Int. J. Agri. Crop Sci., 4(21):1591-1595.

Salem, H.M., Y. Abo-Setta, M.A. Aiad, H.A. Hussein and R.A. El-Awady. 2017. Effect of potassium humate and potassium silicate on growth and productivity of wheat plants grown under saline conditions. J. Soil Sci. Agric. Eng., Mansoura Univ., Vol. 8 (11): 577 - 582.

Shannon, M.C., G.W. Bohn and J.D. Mc Creight. 1984. Salt tolerance among muskmelon genotypes during seed emergence and seedling growth. HortSci., 19: 828-830.

Shannon, M.C., L.E. Francois.1978. Salt tolerance of three muskmelon cultivars. J. Am. Soc. Hort. Sci., 103: 127130.

Silva, H.R., N.D. Costa, and O.A .Carrijo. 2005. Exigências de clima e solo e época de plantio. In: SILVA HR; COSTA ND. (eds). Melão: produção, aspectos técnicos. Brasília: Embrapa. p. 23-28.

Sivritepe, H.O. and A. Eris. 2003. The effects of $\mathrm{NaCl}$ priming on salt tolerance in melon seedlings grown under saline conditions. Sci. Hort. 97:229-237.

Snedecor, G.W. and W.G. Cochran.1969.Statistical methods 6th ed. Iowa State Univ. Press, Iowa, U.S.A

Wininger, k. F. A. and J.W. Ludwing.1974. Methodem der qualitats burteilung bei kartoffeln fur den menschlincher. Konsum. Potato Res., 17:434-465.

Zkan, S. H. O*, S. Nuray, E. Atilla and Ece Turhan. 2005. The effects of $\mathrm{NaCl}$ pre-treatments on salt tolerance of melons grown under long-term salinity. Scientia Horticulturae, 106: 568-581. 


\section{الملخص العريي \\ تأثير ملوحة مياه الري علي نمو وانتاجية خمس سلالات جديدة لمحصول القاوون \\ محمد عيسي أبو قمر - مصطفي أحمد شمة}

الموسمين. سجلت نتائج السلالة G3 أعلى قيمة لمتوسط وزن الثمرة / نبات والمحصول الكلي لكل نبات (كجم) تليها السلالة G4 خلال موسمى النمو . بالنسبة إلى صفات دليل

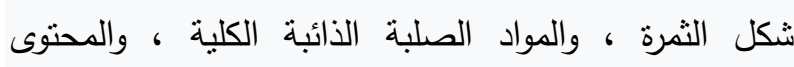
الرطوبي بالثمار تأثرت معنويا باختلاف مستويات ملوحة

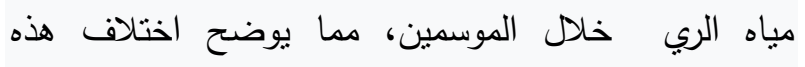
التراكيب الوراثية في تركيبها الجيني. أيضا أظهرت النتائج ان السلالات G3 و G4 كان لها أكبر قدر من الصفات المرغوبة وأعطت أعلى درجة تحمل لمعاملات الري بالمياه الملحية، لذلك نوصي باستخدام هذه السلالات إما في بل بالياه

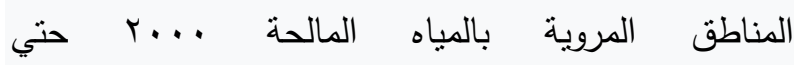
. . . . . . .

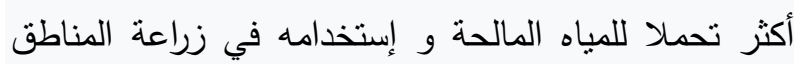
التى لا تتوفر بها مياه عذبة و التي تروي بمياه مالحة.
أجريت التجارب الميدانية في قسم بحوث الاراضي

الملحية والقلوية ، معهذ بحوث الاراضي والمياه ، مركز

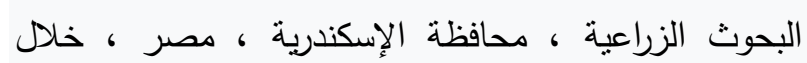

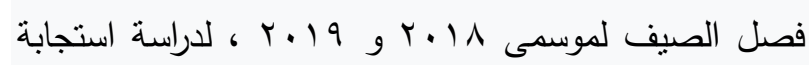
خمسة تراكيب وراثية مختلفة من زراعة القاوون لثناثة

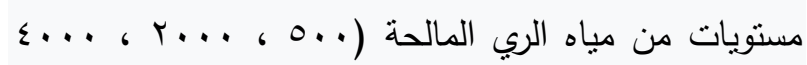
جزء في المليون). التراكيب الوراثية المستخدمة هي الصنف اه لهن المحلي مص مطروح (G1) ، السلالة بr (G2) ، السلالة

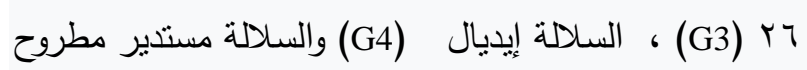

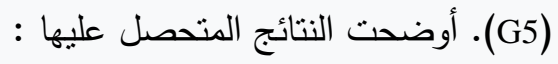
أن كلا من صفة طول النبات وعدد الأفرع / نبات تأثرت معنويا بالنقصان نتيجة معاملات الرى بالمياة المالحة

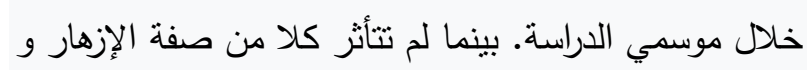

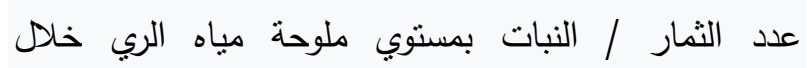

